\title{
Melatonin differences between day and night milk in primiparous holstein friesian and jersey dairy cattle
}

\section{Saim Boztepe ( $\square$ sboztepe@selcuk.edu.tr)}

Selçuk Üniversitesi: Selcuk Universitesi https://orcid.org/0000-0003-1096-9141

İsmail KESKIN

Selçuk Üniversitesi: Selcuk Universitesi

Ahmet SEMACAN

Selcuk University: Selcuk Universitesi

Fikret AKYUREK

Selçuk Üniversitesi: Selcuk Universitesi

İbrahim AYTEKIN

Selçuk Üniversitesi: Selcuk Universitesi

Ozcan SAHIN

Selçuk Üniversitesi: Selcuk Universitesi

\section{Research Article}

Keywords: Holstein Friesian, Jersey, Daytime Milk, Nighttime Milk, Melatonin

Posted Date: November 16th, 2021

DOI: https://doi.org/10.21203/rs.3.rs-1065405/v1

License: (c) (i) This work is licensed under a Creative Commons Attribution 4.0 International License.

Read Full License 


\section{Abstract}

This study was conducted to determine the levels of melatonin in the day and night milk of Holstein and Jersey cows. In the study, samples of daytime milk produced from 27 head of Holstein and 27 head of Jersey cows in the first lactation, which were raised in a private dairy cattle enterprise in the Kaşınhanı neighborhood of Meram district of Konya city Turkey, and night milk samples taken from the same cows that were blackened for one (1) week were used. Melatonin levels in milk samples taken from day and night milk were determined separately for Holstein and Jersey cows with the help of Bovine Melatonin (MLT) Elisa Kit.

In the study, it was determined that the ratio of melatonin in day and night milk in Holstein cows was $2.912 \mathrm{pg} / \mathrm{ml}$ and $11.314 \mathrm{pg} / \mathrm{ml}$, respectively, and the ratio of melatonin in Jersey cows was $2.924 \mathrm{pg} / \mathrm{ml}$ and $6.954 \mathrm{pg} / \mathrm{ml}$ in the same order. The difference between the melatonin levels of the day and night milk of Holstein and Jersey cows was found to be statistically significant $(p<0.01)$.

At the end of the study, it can be stated that night milk can be used for medical purposes and a new production source may arise for producers since there is a significant difference in melatonin between day and night milk.

\section{Introduction}

The presence of a higher amount of melatonin in milk produced in the dark than in day milk and its relationship with human health has recently attracted the attention of researchers and has led to a remarkable increase in the number of publications on the subject.

Özçelik et al., (2013) reported from studies conducted in humans that while the blood concentration of melatonin is around $0-20 \mathrm{pg} / \mathrm{dl}$ during the daytime, it rises to $50-200 \mathrm{pg} / \mathrm{dl}$ at night. An average of $30 \mathrm{mg}$ of melatonin is synthesized overnight. There are many factors that affect melatonin synthesis. Light is one of these factors. This hormone, which is secreted during sleep, is secreted intensively, especially at night (between 23:00 and 05:00). For this intense secretion to occur, the environment must be dark. This mechanism is similar in other mammals (Jainudeen et al., 2000; Balch, 2010).

Romanini et al., (2019) determined the highest concentration of melatonin in individual cow's milk as $41.94 \mathrm{pg} / \mathrm{ml}$. They reported that there are seasonal changes and that the highest concentration of melatonin is reached at night in winter. There are also studies revealing the relationship between health and melatonin secretion in night milk (Valtonen et al., 2005). Related to melatonin helping to improve symptoms of jetlag (a problem more commonly experienced by people who travel a lot and flight crews in general, with interrupted sleep, early waking, excessive sleepiness, difficulty falling asleep, and reduced sleep quality being the most prominent effects of jetlag) are reports (Liu and Borjigin, 2006; Srinivasan et al., 2008). At the same time, melatonin is a very powerful antioxidant, stronger than vitamin C, E or beta carotene, preventing harmful oxidation. In this way, it can reduce the risk of hypertension, heart attack and some types of cancer. In addition, it has been stated that it can be useful in the treatment of 
Alzheimer's and cancer, preventing the regulation of the immune system, memory loss, vascular occlusion and stroke. Also, there is no toxic level of melatonin consumption (Balch, 2010). Romanini et al., (2019) reported that melatonin-rich night milk produced and marketed has benefits for public health and business people.

Photoperiod, which is defined as the duration of daylight that the animal is exposed to for 24 hours, also significantly affects milk yield. Photoperiod is applied in two ways as long day photoperiod (16-18 hours of continuous daylight exposure and 6-8 hours of dark exposure) and short day photoperiod (8 hours of daylight and 16 hours of dark exposure). This study was carried out in January, when the light period of the day is 15 hours and the dark period is 9 hours. The aim here is to determine the melatonin levels in milk produced day and night, as well as to reveal whether this effect varies from breed to breed.

This study was carried out to reveal the differences between the melatonin levels in the daytime and nightly synthesized milk of Holstein and Jersey cows, to determine what the production possibilities of night milk rich in melatonin are and whether there is a difference between the breeds.

\section{Material And Methods}

\section{Material}

The research was carried out in January and the photoperiod is 11 hours of light and 13 hours of darkness in Konya, where the research was conducted during this period. The average daily milk yield and days in milk of the cows in the first lactation, which constitutes the research material, were determined as $30.63 \pm 0.72 \mathrm{~kg}-75.91 \pm 4.21$ day and $17.16 \pm 1.44 \mathrm{~kg}-73.25 \pm 4.01$ day for Holsteins and Jerseys, respectively. Milk samples to be analyzed were obtained by milking the milk produced by 27 Holstein and 27 Jersey cows lighted 150 lux at eye level in night time in the first lactation in the afternoon (at 15:00-17:00 milking time) during the day. Then, Holstein and Jersey cows were kept in the barn, which was completely dark at night, for a week, and the nightly synthesized milk was obtained by milking before sunrise (at 3:00-5:00 milking time). Samples of both day and night milk for both breeds were taken into $50 \mathrm{ml}$ tubes homogeneously to represent the total milk with the help of the milk sampling apparatus that can be mounted on the milking system.

\section{Method}

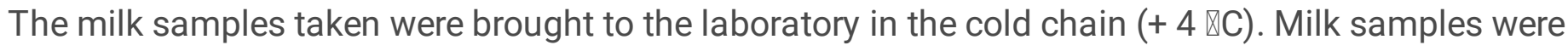
homogenized at $+4 \mathbb{\triangle C}$, taken into $8 \mathrm{ml}$ polypropylene tubes and transferred to the laboratory in a cold chain and dark environment.

After all samples were obtained, the analysis phase was started. Centrifugation was performed twice at $4500 \mathrm{rpm}$ for 15 minutes at $+4 \mathbb{} \mathbb{C}$ in the laboratory. After each centrifugation, the fat layer accumulated in the upper part was separated, and the milk samples, which were completely separated from the fat, were 
kept at -80 degrees until the working day. On the working day, the samples were thawed first at $-20 \otimes C$, then at $+4 \otimes C$ and finally at room temperature. After dissolution, homogenization was achieved by vortexing. Homogenized samples were analyzed using IBL brand Melatonin direct Saliva ELISA (NonExtraction) and in accordance with the kit procedure, Rayto RT-2600 Microplate Washer (India) and BMG LABTECH (German) Enzyme-Linked Immuno Sorbent Assay in Selcuk University Faculty of Medicine Biochemistry Laboratory. (ELISA) Melatonin levels were determined in $\mathrm{pg} / \mathrm{ml}$ via ELISA reader. The quantitation limits of the melatonin kit used are between $0.5-50 \mathrm{pg} / \mathrm{ml}$ and the samples were not diluted.

\section{Statistical analysis}

Analysis of the differences between melatonin levels in day and night milk in Holstein and Jersey cows was performed according to the repeated measurements experiment design (Two Factors Experiments With Repeated Measurements On One Factor Levels) in order to prevent dependence, since the samples were taken from the same animals before and after darkening (Gürbüz et al., 2003). Statistical analyzes were made with the help of the RStudio statistical package program.

\section{Results And Discussion}

At the end of the study, it was determined that the level of melatonin in Holstein cows was $2.912 \mathrm{pg} / \mathrm{ml}$ in milk synthesized during the day and $11.314 \mathrm{pg} / \mathrm{ml}$ in milk synthesized at night. In the samples examined in Holstein cows, it was observed that the lowest melatonin value in day milk was 1.168, the highest melatonin value was 5.887, and the melatonin ratio in night milk was between 3.520 and 21.510 (Table 1). In Jersey cows, on the other hand, melatonin level was determined as $2.924 \mathrm{pg} / \mathrm{ml}$ in milk synthesized during the day and as $6.954 \mathrm{pg} / \mathrm{ml}$ in night milk. The melatonin ratios in day milk of Jersey cows ranged from 1.085-4.577, and in night milk from 3.422 to 15.722 (Table 1). The melatonin level in night milk of Holstein cows was approximately 3.9 times the milk synthesized during the day and this difference was statistically significant $(p<0.01)$. In Jersey cows, the melatonin level in night milk was approximately 2.4 times the milk synthesized during the day, and this difference was statistically significant $(p<0.01)$. While the difference between the melatonin levels of milk synthesized during the day in Holstein and Jersey cows was statistically insignificant ( $p>0.05$ ), the difference in milk synthesized at night was statistically significant $(p<0.01)$.

The differences between melatonin levels in night and day milk of Holstein and Jersey cows can also be seen in Figure 1.

According to Holzmann et al., (2019), the ration supplemented with vitamins (C) did not affect the concentration of melatonin in total milk. However, in the night milk, the melatonin level was $6.57 \mathrm{pg} / \mathrm{ml}$ in the cows fed the unsupplemented ration, while it was $11.06 \mathrm{pg} / \mathrm{ml}$ in the fortified ration group. Milk expressed at night showed melatonin concentrations 1.43 to 2.38 times higher than total milk per day. According to Romanini et al., (2019), in their study investigating melatonin levels and sources in cow's milk, reported differences in levels of melatonin in night milk and total milk according to winter and 
summer months. In the low yield group, the level of melatonin was found to be around $22 \mathrm{pg} / \mathrm{ml}$ in night milk in winter and around $10 \mathrm{pg} / \mathrm{ml}$ in summer, while it was around $8 \mathrm{pg} / \mathrm{ml}$ in winter and $6 \mathrm{pg} / \mathrm{ml}$ in summer in total milk. In the high yield group, it was found as $16 \mathrm{pg} / \mathrm{ml}$ in night milk in winter and 11 $\mathrm{pg} / \mathrm{ml}$ in summer, while it was determined as $9 \mathrm{pg} / \mathrm{ml}$ in winter and $4 \mathrm{pg} / \mathrm{ml}$ in total milk. The values found in the current study were similar to those reported by Romanini et al., (2019). While Asher et al., (2015) found lower levels of melatonin levels in milk under dark and limited lighting conditions at night, researchers reported values between $15-20 \mathrm{pg} / \mathrm{ml}$ in the group with limited lighting, while melatonin level was around $30 \mathrm{pg} / \mathrm{ml}$ in night milk. Sahin et al., (2021), it was determined that the melatonin level in day milk of first lactation cows of Holstein breed was $103.70 \pm 6.61 \mathrm{pg} / \mathrm{ml}$ and $163.13 \pm 8.96 \mathrm{pg} / \mathrm{ml}$ in night milk. The difference between melatonin levels of day and night milk was statistically significant $(P<0.01)$. The probable reason for this difference is that the kits used to determine the melatonin level are different (In some kits, the reading range for melatonin level varies between 0 and 1000 ((MYBIOSOURCE brand Bovine Melatonin (MLT) ELISA Kit (Competitive ELISA)), in some kits this reading is between 0.5 and 50 . (IBL, Melatonin direct Saliva ELISA (Non-Extraction) varies) It may also be that the season and yield level of milk samples are different (high or low yield) (Asher et al., 2015).

\section{Conclusion}

Melatonin has a vital role for humans and is necessary for a healthy life. Sources rich in melatonin, especially milk, should be evaluated for a healthy and happy life. In Finland and Germany, melatonin-rich milk produced at night from cattle under the name of "night milk" has begun to be produced commercially (Valtonen et al., 2005; Mullins, 2010). Valtonen et al., (2005) reported that even the lowest melatonin dose of $0.1 \mathrm{mg}$ was 10 times higher than the total melatonin secreted at night. In other words, it is not possible to meet this amount by consuming milk rich in melatonin. Accordingly, "night milk" produced from cows should be consumed at least half a liter based on the reports of Valtonen et al., (2005) in adults, especially children and the elderly, as a supplement to the melatonin secretion of patients. Regarding this issue, Valtonen et al., (2005) reported that melatonin secretion decreases with age and that they use night milk as a material for the elimination of sleep disorders in elderly people, and that they obtain positive results when the patients are given about 0.61 liters/day. Bae et al., (2016) compared the effects of consuming regular milk containing $100 \mathrm{pg}$ melatonin and $47.5 \mathrm{mg}$ tryptophan amino acids and a glass of overnight milk containing $1000 \mathrm{pg}$ melatonin and $58.24 \mathrm{mg}$ tryptophan amino acids. As a result, it has been reported that a glass of night milk containing 1000 pg melatonin provides an increase in sleep comfort and a decrease in insomnia throughout the day.

In some countries, milk rich in melatonin is marketed as "night time milk" separately from normal milk. In Turkey, it is necessary to make legal regulations in this regard and to produce and market this milk rich in melatonin. In this way, milk producers will be able to provide an additional income.

\section{Declarations}

\section{Authors' contribution}


SB and AS designed the study. Statistical analysis of the study was done by IK and IA. Milk samples taken from the animals were taken by IA and OS. Milk samples were analyzed by FA and IK. All authors wrote and approved the manuscript.

\section{Data Availability}

Data will be provided by corresponding author on reasonable request

\section{Compliance with ethical standards}

\section{Conflict of Interest}

The authors declare that they have no conflict of interest.

\section{Informed consent}

All authors have given their consent that this work is valid and represent their views of the study and have given their consent for this work to be published.

\section{Statement of animal rights}

This work did not involve the use of animal for laboratory studies. There is no violation of animal right.

\section{References}

1. Asher, A., Sbabtay, A., Brosh, A., Eitam, H., Agmon, R., Cohen-Zinder, M., Zubidat, A.E., Haim, A., 2015. "Chrona-functional milk": The differecence between melatonin concentration in night-milk versus day-milk under different illumination conditions. Chronabiol Int., 32:1409-1416.

2. Bae, S.M., Jeong, J., Jeon, H.J., Bang, Y.R., Yoon, I.Y., 2016. Effects of melatonin-rich milk on mild insomnia symptoms. Sleep Medicine Research, 7(2): 60-67.

3. Balch P.A., 2010. Health and Fitness, boks.google.com.tr/boks?isbn=1583332367, Erişim Tarihi: 6.9.2010.

4. Gürbüz, F., Başpınar, E., Çamdeviren, H., Keskin, S., 2003. Tekrarlanan Ölçümlü Deneme Düzenlerinin Analizi. Van.

5. Holzmann, V.M.M., Trentin, M., Rego, F.C.A., Filho, L.F.C.C., Ludovico, A., 2019. Melatonin concentration in the milk of cows supplemented with vitamins and milked twice Daily. The Journal Semina Ciencias Agrarias, 40 (5): 2017-2026.

6. Jainudeen M.R., Wahid H., Hafez E.S.E., 2000. Sheep and Goats (Chapter 12), Reproduction in Farm Animals, Hafez E.S.E and Hafez B. (ed): 172-179.

7. Liu, T., Borjigin, J., 2006. Relationship between nocturnal serotonin surge and melatonin onset in rodent pineal gland. Journal of Circadian Rythms, 4:12. 
8. Mullins K.J. 2010. Night time milking produces milk with extra melatonin, digitaljournal.com/article/297161 (SEP 7, 2010), Accession Date: 16.09.2010

9. Özçelik, F. M. Erdem, A. Bolu., Gülsün, M., 2013. Melatonin: Genel Özellikleri ve Psikiyatrik Bozukluklardaki Rolü (Melatonin: General Features and its Role in Psychiatric Disorders) Psikiyatride Güncel Yaklaşımlar-Current Approaches in Psychiatry 179-203 doi:10.5455/cap.20130512

10. Romanini, E.B., Volpato, A.M., dos Santos, J.S., de Santana, E.H.W., de Souza, CHB., Ludovico, A., 2019. Melatonin concentration in cow's milk and sources of its variation. Journal of Applied Animal Research. 47(1): 140-145.

11. RStudio https://www.rstudio.com/ Access date: 25.03.2021

12. Srinivasan, V., Spence, D.W., Pandi-Perumal, S.R., Trakht, I., Cardinali, D.P., 2008. Jet lag: Therapeutic use of melatonin and possible application of melatonin analogs. Travel Medicine and Infectious Disease. (6): 17-28.

13. Şahin, Ö., Akyürek, F., Boztepe, S., Aytekin, I.., Keskin, I., 2021. Determination of melatonin differences between day and night milk in dairy cattle. Journal of Agricultural Sciences (Tarim Bilimleri Dergisi) 2021271 - 5 DOI: 10.15832/ankutbd. 687769

14. Valtonen M., Niskanen L., Kangas A-P, Koskinen T., 2005. Effect of melatonin-rich night-time milk on sleep and activity in elderly institutionalized subjects. Nordic Journal of Psychiatry, 59 (3): 217-221.

\section{Tables}

Due to technical limitations, Table 1 is only available as a download in the Supplemental Files section.

\section{Figures}

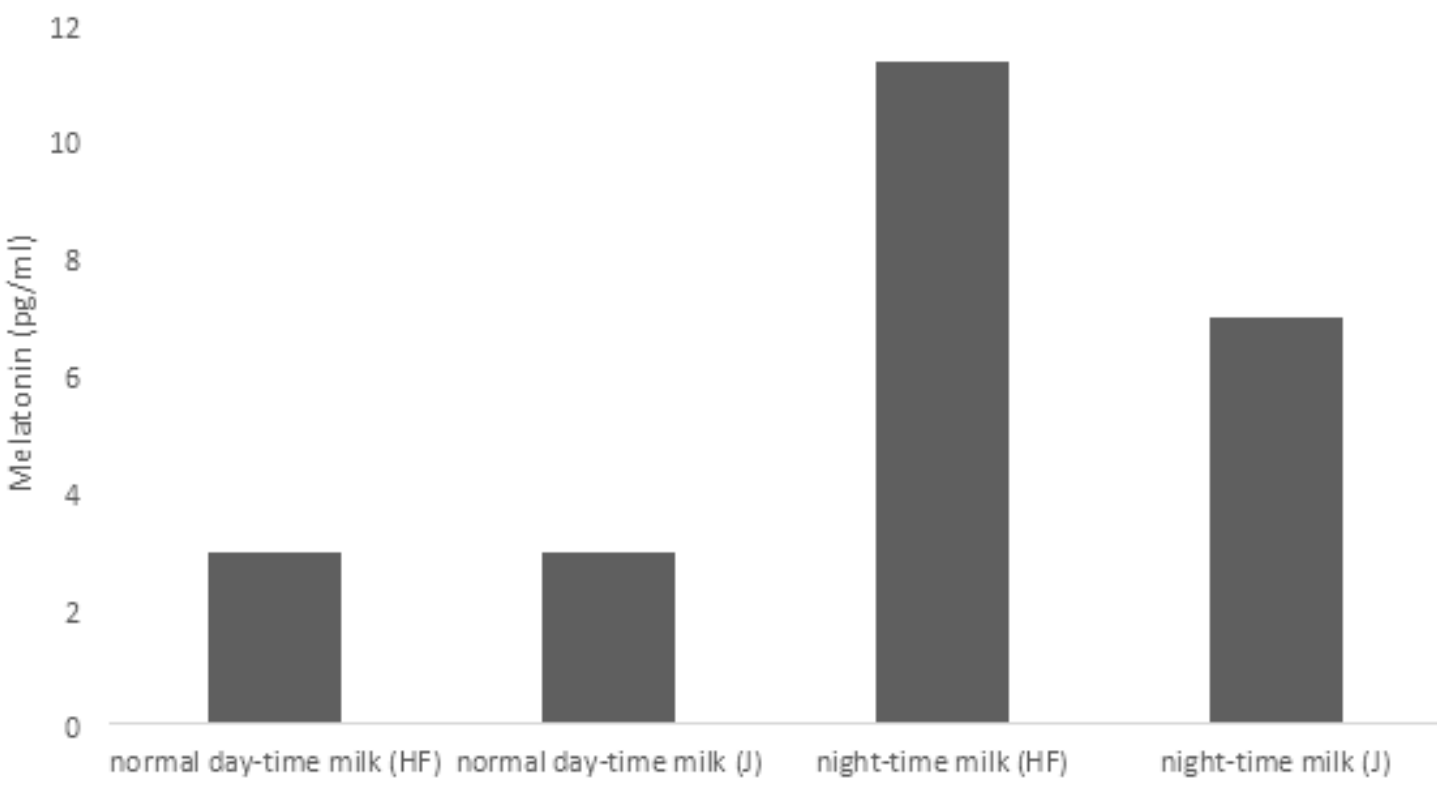

Figure 1 
Melatonin levels in day and night milk in Holstein Friesian (HF) and Jersey (J) cows

\section{Supplementary Files}

This is a list of supplementary files associated with this preprint. Click to download.

- Table1.docx 